\title{
Penentuan Kadar Enzim Kolinesterase pada Petani Pengguna Pestisida Organofosfat Berdasarkan Frekuensi Penyemprotan
}

\section{Determination of Cholinesterase Enzyme Levels in Farmers Using Organophosphate Pesticides Based On The Frequency Of Spraying}

\author{
Devi Yoga Saputra ${ }^{1}$, Purwati ${ }^{1}$, Tri Harningsih ${ }^{1}$ \\ syahputrayoga777@gmail.com ${ }^{1}$; purwatiaak@gmail.com²; tri.harningsih@gmail.com ${ }^{3}$ \\ ${ }^{1}$ Sekolah Tinggi Ilmu Kesehatan Nasional \\ Riwayat Artikel: Dikirim Juli 2020; Diterima September 2020; Diterbitkan Oktober 2020
}

\begin{abstract}
Abstrak
Pestisida secara umum diartikan sebagai bahan kimia beracun yang digunakan untuk mengendalikan hama yang merugikan manusia. Pestisida telah digunakan untuk meningkatkan produksi pertanian, perkebunan dan pemberantasan vektor penyakit. Frekuensi penyemprotan dan tingginya volume penggunaan pestisida menunjukkan peran penting pestisida tersebut dalam produksi tanaman, pestisida tersebut tidak dapat dilepaskan dari penanaman pertanian. Kebanyakan petani menyemprot sendiri dan memiliki alat penyemprot sendiri sehingga mereka memiliki fleksibilitas untuk menyemprot. Penanam sayuran memiliki risiko keracunan pestisida yang tinggi. Penelitian ini menggunakan metode studi literatur. Pengumpulan data menggunakan data sekunder yang diambil dari jurnal ilmiah dan karya ilmiah rentan 10 tahun terakhir. Analisis data menggunakan analisis deskriptif. Enzim kolinesterase merupakan enzim yang terdapat pada cairan seluloid. Enzim ini berfungsi menghentikan kerja asetilkolin dengan cara menghidrolisis menjadi kolin dan asam asetat. Asetilkolin adalah saraf pengantar yang terletak di seluruh sistem saraf pusat (SSP), saraf otonom (simpatis dan parasimatik), dan sistem saraf somatik. Hasil penelitian menyatakan bahwa 4 jurnal menyatakan ada hubungan antara frekuensi penyemprotan dengan kadar enzim cholinesterase, sedangkan 2 jurnal menyatakan tidak ada hubungan. Frekuensi penyemprotan berpengaruh terhadap penurunan kadar enzim kolinesterase pada petani pengguna pestisida organofosfat.
\end{abstract}

Kata Kunci : frekuensi, kolistenarase,organofosfat, penyemprotan

\begin{abstract}
Pesticides are generally interpreted as toxic chemicals that are used to control pests that harm humans. Pesticides have been used to increase agricultural production, plantations and eradicate disease vectors. The frequency of spraying and the high volume of pesticides used indicates the decisive role of these pesticides in crop production, these pesticides cannot be released from agricultural planting. Most farmers spray themselves and have their own sprayers so that they have the flexibility to spray. Vegetable growers have a high risk of pesticide poisoning. This research uses the literature study method. Data collection uses secondary data taken from scientific journals and scientific papers with the last 10 years vulnerable. Data analysis uses descriptive analysis. Cholinesterase enzyme is an enzyme found in celluloid fluid. It used to stop the action of acetylcholine by hydrolyzing into colin and acetic acid. Acetylcholine is an introductory nerve located in the entire central nervous system, autonomic nerve (sympathetic and parasymatic) and the somatic nervous system. The
\end{abstract}


results of the study stated that 4 journals stated that there was a correlation between the frequency of spraying on the enzyme level cholinesterase, while 2 journals stated that there was no relationship. The frequency of spraying affects the decrease in the level of theenzyme cholinesterase in organophosphate pesticide farmers.

Keywords: organophosphate, frequency, spraying, cholinesterase

\section{Pendahuluan}

Pestisida secara umum diartikan sebagai bahan kimia beracun yang digunakan untuk mengendalikan jasad pengganggu yang merugikan manusia menurut. Pestisida telah digunakan secara luas untuk meningkatkan produksi pertanian, perkebunan dan pemberantasan vektor penyakit. Frekuensi penyemprotan serta tingginya volume pestisida yang digunakan menunjukkan adanya peranan yang menentukan dari pestisida ini terhadap produksi tanaman sehingga pestisida ini tidak dapat dilepaskan dari penanaman sayuran. Terlebih, sebagian besar petani melakukan penyemprotan sendiri (terutama yang lahan garapannya kecil) dan memiliki alat penyemprot sendiri sehinggga mereka mempunyai keleluasaan untuk melakukan penyemprotan. Oleh karena itu, petani sayuran memiliki risiko yang tinggi keracunan pestisida (Rustia. dkk, 2010).

Organofosfat merupakan insektisida anticolinesterase karena sifatnya menghambat enzim kolinesterase pada syaraf. Senyawa organofosfat bersifat tidak stabil sehingga dari segi lingkungan senyawa ini lebih baik daripada organoklorin. Akan tetapi, senyawa organofosfat lebih bersifat toksik terhadap hewan-hewan bertulang belakang dibanding organoklorin karena dapat mempengaruhi sistem syaraf dengan cara menghambat aktivitas enzim kolinesterase dalam Tubuh (acetylcholinesterase) (Rustia. dkk, 2010).

Kolinesterase adalah enzim (suatu bentuk dari katalis bilogik) di dalam jaringan tubuh yang berperan untuk menjaga agar otototot, kelenjar-kelenjar dan sel-sel syaraf bekerja secara terorganisir dan harmonis. Jika aktivitas kolinesterase jaringan tubuh secara cepat sampai pada tingkat yang rendah, akan berdampak pada bergeraknya serat-serat otot secara sadar dengan gerakan halus maupun kasar. Petani dapat mengeluarkan air mata akibat mata yang teriritasi serta mengalami gerakan otot yang lebih lambat dan lemah (Rustia. dkk, 2010).
Berdasarkan data dari WHO (World Health Organization) menyatakan bahwa setiap tahun terjadi $1-5$ juta kasus keracunan pestisida pada pekerja pertanian dengan tingkat kematian mencapai 220.000 korban jiwa, sekitar 80\% keracunan pestisida dilaporkan terjadi di negaranegara berkembang sedangkan di Indonesia telah terjadi beberapa kasus keracunan yang disebabkan oleh pestisida, data pemeriksaan aktivitas cholinesterase yang dilakukan UPT Balai Hiperkes dan KK Provinsi Bali pada tahun 2013, prevalensi petani di Bali yang mengalami keracunan pestisida sebesar 41\% (Samosir. dkk, 2017).

Enzim kolinesterase adalah suatu enzim yang terdapat pada cairan seluluer yang fungsinya untuk menghentikan aksi dari pada acetylcholine dengan jalan menghidrolisis menjadi colin dan asam asetat. Acetylcholine adalah pengantar saraf yang berada pada seluruh sistem saraf pusat (SSP), saraf otonom (simpetik dan parasimatik) dan sistem saraf somatik (Marisa dan Pratuna, 2018).

Kadar enzim kolinesterase dapat dipengaruhi oleh beberapa faktor, faktor tersebut antara lain faktor internal yang terdiri dari usia, status gizi, jenis kelamin, dan pengetahuan, sedangkan faktor eksternal akibat paparan pestisida antara lain dosis, lama penyemprotan, tindakan penyemprotan terhadap arah angin, waktu penyemprotan, frekuensi penyemprotan, jumlah jenis pestisida yang digunakan, dan penggunaan alat pelindung diri (Rahmawati. dan Martiana, 2014).

Penelitian yang dilakukan Budiawan (2013) menyebutkan bahwa adanya hubungan antara frekuensi penyemprotan terhadap kadar enzim kolinesterase terhadap petani bawang merah di Ngurengsiti Pati. Semakin sering petani melakukan penyemprotan dengan menggunakan pestisida, maka akan semakin besar pula kemungkinan untuk terjadinya keracunan, dari penelitian tersebut dapat diketahui bahwa adanya efek negatif dari penggunaan pestisida terhadap enzim 
kolinesterase pada petani. Berdasar latar belakang tesebut, maka peneliti tertarik melakukan studi literature penelitian dengan judul "Penentuan Kadar Enzim Kolinesterase Pada Petani Pengguna Pestisida Organofosfat Berdasarkan Frekuensi Penyemprotan" untuk mengatasi hama di lahan pertaniannya.

\section{Metode Penelitian}

Jenis penelitian yang digunakan adalah deskriptif. Data-data yang digunakan dalam penelitian ini selain bersumber dari data primer penelitian juga berasal dari saduran sumber buku, artikel, dan jurnal atau dokumendokumen yang relevan dengan permasalahan yang dikaji. Penelusuran pustaka tidak hanya untuk langkah awal menyiapkan kerangka penelitian akan tetapi sekaligus memanfaatkan sumber-sumber perpustakaan untuk memperoleh data penelitian variabel pada penelitian ini bersifat fleksibel. Sedangkan data dituangkan per sub bab sehingga menjawab rumusan masalah penelitian

\section{Hasil dan Pembahasan}

Berdasarkan data penelitian frekuensi penyemprotan terhadap kadar enzim cholinesterase pada petani pengguna pestisida organofosfat. Selama ini penggunaan pestisida oleh petani bukan atas dasar keperluan secara indikatif, namun di semprotkan secara terusmenerus artinya ada atau tidaknya hama tanaman, pestisida akan terus disemprotkan. Tehnik penyemprotan yang kadang tidak melawan arah angin, menyebabkan petani akan menghirup pestisida tanpa disadarinya (Mahyuni, 2015).

Penggunaan pestisida golongan organofosfat di Indonesia masih sangat umum di kalangan pertanian untuk mengusir atau membasmi hama. Penggunaan pestisida golongan organofosfat ini jadi banyak dikhawatirkan penggunaannya karena selain mengusir hama pestisida ini dapat mengakibatkan keracunan pada petaninya langsung. atau pada konsumen yang mengkonsumsi hasil pertanian yang disemprotkan pestisida golongan organofosfat ini. Keracunan akibat senyawa organofosfat akan menyebabkan otot-otot menjadi kejang dan penderita akan menggelepar. Gejala-gejala lainnya dari keracunan senyawa organofosfat adalah gemetar, penglihatan menjadi kabur, mual, lemah, kejang, diare dan sakit dada.
Tanda-tanda lainya ialah berkeringat, mata berair, air liur banyak keluar, denyut jantung lebih cepat, dan muntah-muntah. Jika keracunan sangat serius, akan menyebabkan menggelepar, kehilangan reflek dan tidak sadarkan diri. Tanpa pertolongan segera dapat berakhir pada kematian. (Prasasti. dan Perwitasari, 2017).

Kadar enzim kolinesterase dapat dipengaruhi oleh beberapa faktor, faktor tersebut antara lain faktor internal yang terdiri dari usia, status gizi, jenis kelamin, dan pengetahuan, sedangkan faktor eksternal akibat paparan pestisida antara lain dosis, lama penyemprotan, tindakan penyemprotan terhadap arah angin, waktu penyemprotan, frekuensi penyemprotan, jumlah jenis pestisida yang digunakan,dan penggunaan alat pelindung diri (Rahmawati, 2014).

Tabel 1. Hasil Uji Frekuensi

Penyemprotan Terhadap Kadar Enzim

Kolinesterase Pada Petani Pengguna Pestisida Organofosfat.

\begin{tabular}{|c|c|c|c|c|c|c|}
\hline \multirow[b]{2}{*}{$\begin{array}{l}\text { Penulis- } \\
\text { Tahun }\end{array}$} & \multirow[b]{2}{*}{ Metode } & \multirow{2}{*}{$\begin{array}{c}\text { Frekuensi } \\
\text { penyempro } \\
\tan \end{array}$} & \multicolumn{3}{|c|}{ Hasil } & \multirow{2}{*}{$\begin{array}{c}\text { Kesimp } \\
\text { ulan }\end{array}$} \\
\hline & & & $\begin{array}{c}\text { Norm } \\
\text { al }\end{array}$ & $\begin{array}{c}\text { Tidak } \\
\text { Norm } \\
\text { al }\end{array}$ & Jumlah & \\
\hline \multirow{2}{*}{$\begin{array}{l}\text { Budiawa } \\
\text { n } \\
2013\end{array}$} & \multirow{2}{*}{$\begin{array}{c}\text { Test } \\
\text { Cholines } \\
\text { terase }\end{array}$} & Rendah & 16 & 7 & 23 & \multirow{2}{*}{$\begin{array}{c}\text { Ada } \\
\text { hubung } \\
\text { an }\end{array}$} \\
\hline & & Tinggi & 9 & 18 & 27 & \\
\hline $\begin{array}{l}\text { Ma'arif, } \\
\text { dkk- } \\
2016\end{array}$ & $\begin{array}{c}\text { Spektofo } \\
\text { tometri }\end{array}$ & Sering & - & - & - & $\begin{array}{c}\text { Tidak } \\
\text { ada } \\
\text { hubung } \\
\text { an } \\
\end{array}$ \\
\hline \multirow{2}{*}{$\begin{array}{l}\text { Zulmi, } \\
\text { Nizar- } \\
2016\end{array}$} & \multirow{2}{*}{$\begin{array}{c}\text { Test } \\
\text { Cholines } \\
\text { terase }\end{array}$} & $\begin{array}{c}<3 \text { kali/ } \\
\text { minggu }\end{array}$ & 30 & 4 & 34 & \multirow{2}{*}{$\begin{array}{c}\text { Ada } \\
\text { hubung } \\
\text { an }\end{array}$} \\
\hline & & $\begin{array}{c}\geq 3 \text { kali/ } \\
\text { minggu }\end{array}$ & 3 & 0 & 3 & \\
\hline \multirow{2}{*}{$\begin{array}{l}\text { Annida, } \\
\text { Sumayya } \\
\text { h-2018 }\end{array}$} & \multirow{2}{*}{$\begin{array}{c}\text { Randix } \\
\text { Butyryl } \\
\text { Kolinest } \\
\text { erase } \\
\text { (Serum) }\end{array}$} & $\begin{array}{c}\leq 2 \text { kali/ } \\
\text { minggu }\end{array}$ & - & - & - & \multirow{2}{*}{$\begin{array}{c}\text { Ada } \\
\text { hubung } \\
\text { an }\end{array}$} \\
\hline & & $\begin{array}{c}>2 \text { kali/ } \\
\text { minggu }\end{array}$ & - & - & - & \\
\hline $\begin{array}{l}\text { Lucki, } \\
\text { dkk-2018 }\end{array}$ & $\begin{array}{c}\text { Test } \\
\text { Cholines } \\
\text { terase } \\
\text { (Serum) }\end{array}$ & $\begin{array}{c}1-4 \text { kali/ } \\
\text { minggu }\end{array}$ & - & - & - & $\begin{array}{c}\text { Ada } \\
\text { hubung } \\
\text { an }\end{array}$ \\
\hline $\begin{array}{l}\text { Fajriani, } \\
\text { dkk-2019 }\end{array}$ & $\begin{array}{l}\text { Tintome } \\
\text { ter Kit } \\
\text { Lovibon } \\
\text { d } 2000 \\
\text { (Darah) }\end{array}$ & $\begin{array}{c}\leq 2 \text { kali/ } \\
\text { minggu }\end{array}$ & - & - & 12 & $\begin{array}{c}\text { Tidak } \\
\text { ada } \\
\text { hubung } \\
\text { an }\end{array}$ \\
\hline
\end{tabular}

Beberapa metode pemeriksaan enzim kolinesterase dari 6 jurnal yang diacu yaitu Test Cholinesterase, Spektofotometri, Randix Butyryl Kolinesterase, Tintometer Kit Lovibond 2000. Berdasarkan tabel 1 diperoleh bahwa 4 jurnal menyatakan bahwa ada pengaruh frekuensi penyemprotan terhadap kadar enzim kolinesterase. Sedangkan 2 jurnal acuan lainnya 
menyatakan tidak terdapat hubungan pada frekuensi penyemprotan terhadap kadar ezim kolinesterase.

Hasil dari analisis data pada 6 jurnal acuan bahwa frekuensi penyemprotan berpengaruh terhadap enzim kolinesterase. Semakin sering petani melakukan penyemprotan maka enzim kolinesterase pada petani semakin menurun. Semakin sering seseorang melakukan penyemprotan, maka semakin tinggi pula resiko keracunannya. Penyemprotan sebaiknya dilakukan sesuai dengan ketentuan yaitu maksimal 2 kali dalam seminggu (Samosir dkk, 2017).

Penelitian Budiawan

menunjukan hasil Chi Square yang dilakukan terhadap tingkat frekuensi penyemprotan dengan kolinesterase petani didapat $p$ value sebesar 0,011, yang berarti ada hubungan antara tingkat frekuensi penyemprotan dengan kolinesterase petani bawang merah di Ngurensiti Pati. Sejalan dengan penelitian Zulmi, Nizar (2016) diketahui bahwa nilai $\mathrm{p}=$ 0,042 yang berarti ada hubungan antara frekuensi penyemprotan dengan enzim kolinesterase. Penelitian Annida, Sumayyah (2018) didapatkan $\phi$ value $\leq 0,05$ dan penelitian Lucki dkk (2018) dengan $p$ value $=0,026$, sehingga disimpulkan terdapat hubungan antara frekuensi penyemprotan dengan enzim kolinesterase.

Penelitian Ma'arif, dkk (2016) menunjukan tidak ada hubungan dengan $p$ value $=1,000$ disebabkan karena data yang diambil saat mayoritas petani setelah panen padi yang membutuhkan banyak penyemprotan hama. Sejalan dengan penelitian Fajriani, dkk (2019) di Desa Pasirhalang hasil uji statistik dengan metode Chi-square diperoleh nilai p 0,107 yang menunjukan bahwa tidak terdapat hubungan antara frekuensi penyemprotan dengan kadar enzim kolinesterase.

Berdasarkan ulasan jurnal Annida (2018) menyatakan bahwa paparan pestisida pada tubuh manusia dengan frekuensi sering dan dengan interval pendek menyebabkan residu pestisida dalam tubuh manusia menjadi lebih tinggi. Secara tidak langsung kegiatan petani yang mengurangi frekuensi menyemprot dapat mengurangi terpaparnya petani tersebut oleh pestisida. Penelitian Ma'arif (2016) menyatakan bahwa pengetahuan responden mengenai frekuensi menyemprot dan jumlah jenis pestisida yang digunakan mayoritas menjawab berdasarkan pengalaman yang dialami bukan berdasarkan teori.

Menurut Zulmi, Nizar (2016) menyatakan bahwa frekuensi penyemprotan sebaiknya tetap dilakukan sesuai dengan ketentuan agar keracunan akibat pestisida dapat diminimalisir. Frekuensi penyemprotan yang dianjurkan adalah maksimal 2 kali dalam satu minggu. Penyemprotan yang dilakukan dengan frekuensi tinggi tanpa dilengkapi dengan pemakaian alat pelindung diri akan mempengaruhi kadar enzim kolinesterase pada petani (Budiawan, 2013).

Kadar kolinesterase sendiri juga dapat dipengaruhi oleh faktor lain. faktor tersebut antara lain faktor internal yang terdiri dari keadaan gizi, umur, jenis kelamin, kebiasaan merokok, kebiasaan memakai alat pelindung diri (Rahmawati dan Martiana, 2014). Sebagian besar petani melakukan penyemprotan pestisida menurut musim, jika musim hujan maka serangan hama akan lebih banyak daripada musim kemarau, sehingga petani selalu berpatokan pada keadaan tanaman di lapangan, dimungkinkan petani melakukan penyemprotan lebih dari 2 kali dalam seminggu, bahkan melakukan penyemprotan setiap dua kali sehari pada musim hujan. Pengetahuan petani dalam pemakaian alat pelindung diri, banyaknya frekuensi penyemprotan, lama penyemprotan dan higiene perorangan yang diperbolehkan masih kurang. Petani hanya mendapatkan penyuluhan yang singkat dari distributor produk obat yang sering melakukan penawaran produk, itupun tidak disertai pemberian alat pelindung diri seperti penggunaan masker (Budiawan, 2013).

\section{Simpulan}

Frekuensi

penyemprotan mempengaruhi kadar enzim kolinesterase, semakin sering penyemprotan dilakukan maka kadar enzim kolinesterase semakin menurun. Data studi literatur yang diperolah didapatkan 4 jurnal acuan menyatakan bahwa adanya pengaruh frekuensi penyemprotan terhadap kadar kolinesterase pada petani.

\section{Ucapan Terima Kasih}

Penelitian ini didukung oleh Sekolah Tinggi Ilmu Kesehatan Nasional pada tahun 2020. 


\section{Daftar Pustaka}

Annida, Sumayyah. 2018. Hubungan Antara Frekuensi dan Lama Penyemprotan dengan Keracunan Pestisida pada Petani di Desa Srikaton Kecamatan Adiluwih Kabupaten Pringsewu. Skripsi. Fakultas Kedokteran Universitas Lampung Bandar Lampung.

Budiawan, Agung Rosyid. 2013. Faktor Risiko Cholinesterase Rendah pada Petani Bawang Merah. Jurnal Kesehatan Masyarakat, Vol 8, No 2, 198-206

Fajriani, Gita Nur, Fitri Rahmi, dan Roy R. 2019. Hubungan Intensitas Penyemprotan Pestisida Dengan Kadar Kolinesterase Dalam Darah Petani Di Desa Pasirhalang Kabupaten Bandung Barat. Meditory, Vol. 7, No. 2, 66-76.

Lucki, Fitrisya, Yusniar H, dan Nikie Astorina. 2018. Hubungan Masa Kerja, Lama Kerja, Lama Penyemprotan dan Frekuensi Penyemprotan Terhadap Kadar Cholinesterase Dalam Darah pada Petani di Desa Sumberejo Kecamatan Ngablak Kabupaten Magelang. Jurnal Kesehatan Masyarakat (e-Journal), Vol 6, No 6, 128-134.

Ma'arif, Muhammad Imam, Suhartono, dan Nikie Astorina Yunita D. 2016. Studi Prevalensi Keracunan Pestisida Pada Petani Penyemprot Sayur Di Desa Mendongan Kecamatan Sumowono Kabupaten Semarang. Jurnal Kesehatan Masyarakat (E-Journal), Vol 4, No 5, 3543

Mahyuni, L, E, 2015. Faktor Resiko Dalam Penggunaan Pestisida Terhadap Keluhan Kesehatan Pada Petani Di
Kecamatan Berastagi Kabupaten Taro. Kenmas ISSN: 1978-0575 Vol. 9, No. 1.

Marisa. Pratuna, D, N, 2018. Analisa Kadar Cholinesterase Dalam Darah Dan Keluhan Kesehatan Pada Petani Kentang Kilometer Xi Kota Sungai Penuh. Jurnal Kesehatan Perintis (Perintis's Health Journal) Vol.5 Nomor 1.

Prasasti, D. Perwitasari, A, D, 2017. Identifikasi Residu Pestisida Organofosfat Pada Bawang Merah Di Kabupaten Kulon Progo. Media Farmasi Vol. 14 No.2.

Rahmawati, D, Y. Martiana, T, 2014. Pengaruh Faktor Karakteristik Petani Dan Metode Penyemprotan Terhadap Kadar Kolinesterase. The Indonesian Journal of Occupational Safety, Health and Environment, Vol. 1, No. 1.

Rustia, N , H. Wispriyono, B. Susanna, D. Luthfiah, L, N, 2010. Lama Pajanan Organofosfat Terhadap Penurunan Aktivitas Enzim Kolinesterase Dalam Darah Petani Sayuran. Makara, Kesehatan, Vol. 14, No. 2, 95-101.

Samosir, K. Setiani, O. Nurjazuli, 2017. Hubungan Pajanan Pestisida dengan Gangguan Keseimbangan Tubuh Petani Hortikultura di Kecamatan Ngablak Kabupaten Magelang. Jurnal Kesehatan Lingkungan Indonesia 16 (2), 63 $-69$.

Zulmi, Nizar. 2016. Hubungan Antara Frekuensi dan Lama Penyemprotan dan Interval Kontak Pestisida dengan Aktivitas Cholinesterase Petani di Desa Kembangkuning Kecamatan Cepogo. Skripsi. Program Studi Kesehatan Masyarakat Fakultas Ilmu Kesehatan Universitas Muhammadiyah Surakarta. 